\title{
Quantitative Analysis of Terrain Ruggedness in Reindeer Winter Grounds
}

\author{
CHRISTIAN NELLEMANN ${ }^{1}$ and GARETH FRY ${ }^{2}$
}

(Received 20 May 1993; accepted in revised form 31 January 1995)

\begin{abstract}
We report a distinct terrain structure in high-use portions of reindeer (Rangifer tarandus tarandus) winter grounds for two regions within Norway. A new index of terrain ruggedness based on topographic maps was used for analyzing terrain structure within historic high- and low-use portions of wintering areas. Terrain ruggedness was found to be significantly higher in high-use areas. Indices of terrain ruggedness reflecting fine-scale features $(10-20 \mathrm{~m})$ corresponded well with the availability of potential feeding sites (<40 cm snow depth), while contour densities alone did not. Terrain structure should be considered an important habitat attribute for management planning on reindeer winter habitats. The index provides a simple method for quantifying differences in fine-scale ruggedness between habitats.
\end{abstract}

Key words: geomorphology, reindeer, snow, terrain

RÉSUMÉ. On rapporte une structure de terrain différente dans les zones de grande utilisation des sites d'hivernage du renne (Rangifer tarandus tarandus), pour deux régions de Norvège. On a utilisé un nouvel indice d'aspérité du terrain fondé sur les cartes topographiques afin d'analyser la structure du terrain dans les parties de grande utilisation et celles de faible utilisation des zones d'hivernage. On a trouvé que l'aspérité du terrain était nettement plus prononcée dans les parties de grande utilisation. Les indices d'aspérité reflétant les caractéristiques à petite échelle (de 10 à $20 \mathrm{~m}$ ) correspondaient bien à la disponibilité de sites potentiels d'alimentation (<40 cm de couverture de neige), tandis que la densité des lignes de contour seule n'y correspondait pas. La structure du terrain devrait être considérée comme un attribut important de l'habitat lorsqu'on planifie la gestion de l'habitat hivernal du renne. L'indice fournit une méthode simple pour quantifier les différences d'aspérité à petite échelle entre les habitats.

Mots clés: géomorphologie, renne, neige, terrain

Traduit pour la revue Arctic par Nésida Loyer.

\section{INTRODUCTION}

Topography is an important ecological component affecting the distribution of wildlife and vegetation (Beasom et al., 1983). This is particularly true for alpine and arctic environments, where vegetation and snow patterns respond to even minor changes in relief (Shaver et al., 1990; Hall et al., 1991). Topography thereby helps constitute the ecological niche for many arctic plants and animals (Pruitt, 1966; Chernov, 1985; Adamczewski et al., 1988). High ruggedness of terrain causes high diversity of vegetation types and ecotones within short distances (Shaver et al., 1990), enabling herbivores to be more selective for plant species and growth stages (Thing, 1984) with lower energy costs compared to foraging on smooth and more homogenous areas. Rugged terrain is also important for protection against weather and windchill for newborn reindeer calves (Rangifer tarandus tarandus) (Skogland, 1984). Terrain ruggedness affects snowmelt patterns and water drainage, which are major factors determining nutrient availability, plant phenology and biomass (Murray and Miller, 1982; Matthes-Sears et al., 1988; Eastland et al., 1989); the quality of forage for ungulates (Klein, 1990); and possibly even predator avoidance (Bergerud and Page, 1987;
Eastland et al., 1989). Bluffs with reduced snow cover are also known to be important for availability of forage for reindeer in winter (Thing, 1984; Adamczewski et al., 1988). Terrain ruggedness appears to be a major ecological factor for many aspects of wildlife ecology and management. The quantitative analysis of terrain ruggedness may therefore be important in understanding herbivore behaviour and distribution in mountainous and high-latitude environments.

This paper develops a simple index for the analysis of terrain ruggedness that allows for rapid comparison of sites in ecological studies. We use the index to test the hypothesis that reindeer winter grounds consist of rugged terrain giving rise to the frequent occurrence of windblown bluffs with high forage availability.

\section{STUDY AREA}

The study was conducted on data from reindeer winter grounds located in north and central Norway (Fig. 1). The winter grounds were defined as areas where reindeer were located during December-April. The winter grounds in the north were located in Finnmark around Karasjok and

\footnotetext{
${ }^{1}$ Department of Biology and Nature Conservation, P.O. Box 5014, Agricultural University of Norway, N-1432 Ås, Norway; present address: Norwegian Institute of Land Inventory, P.O. Box 115, Drøbakveien 11, N-1430 Ås, Norway

2 Norwegian Institute for Nature Research, P.O. Box 5064, N-1432 Ås, Norway

(C) The Arctic Institute of North America
} 
Kautokeino, where approximately 130000 reindeer are located in winter within approximately $17000 \mathrm{~km}^{2}$ (Vorren, 1962; Hætta et al., 1994). The region in central Norway included the Rondane Range, where approximately 2800 reindeer inhabit the Rondane National Park and vicinity, an area approximately $3000 \mathrm{~km}^{2}$ (Fig. 1). Considerable variation in terrain exists both within and between wintering areas, but both are dominated by alpine vegetation, ranging from snowbed vegetation to lichen heath communities and barren rock. The areas in Finnmark consist of relatively flat and rolling hills, while Rondane has more mountainous and occasionally very steep terrain.

\section{METHODS}

Data on historic use of winter grounds were obtained from Vorren (1962) and Bråtå (1986), who identified the traditional, seasonally-preferred habitats of reindeer on the basis of surveys of reindeer herders and rangers and their own field observations. Within the winter grounds, areas were classified as high-use (used $>150$ days in winter) or as low-use (used < 150 days) (Vorren 1962; Bråtå, 1986; Hætta et al., 1994). In Rondane, the low-use areas included all areas within the park boundary (Fig. 1).

Within the high-use areas, we randomly selected 40 sites, each $3 \times 3 \mathrm{~km}, 20$ sites in Finnmark and another 20 in Rondane. As a control, 20 sites were randomly selected in low-use areas in each region. A total of 80 sites were analyzed, all located in alpine terrain. Since the steepest and most rugged areas are generally inaccessible to reindeer in winter,

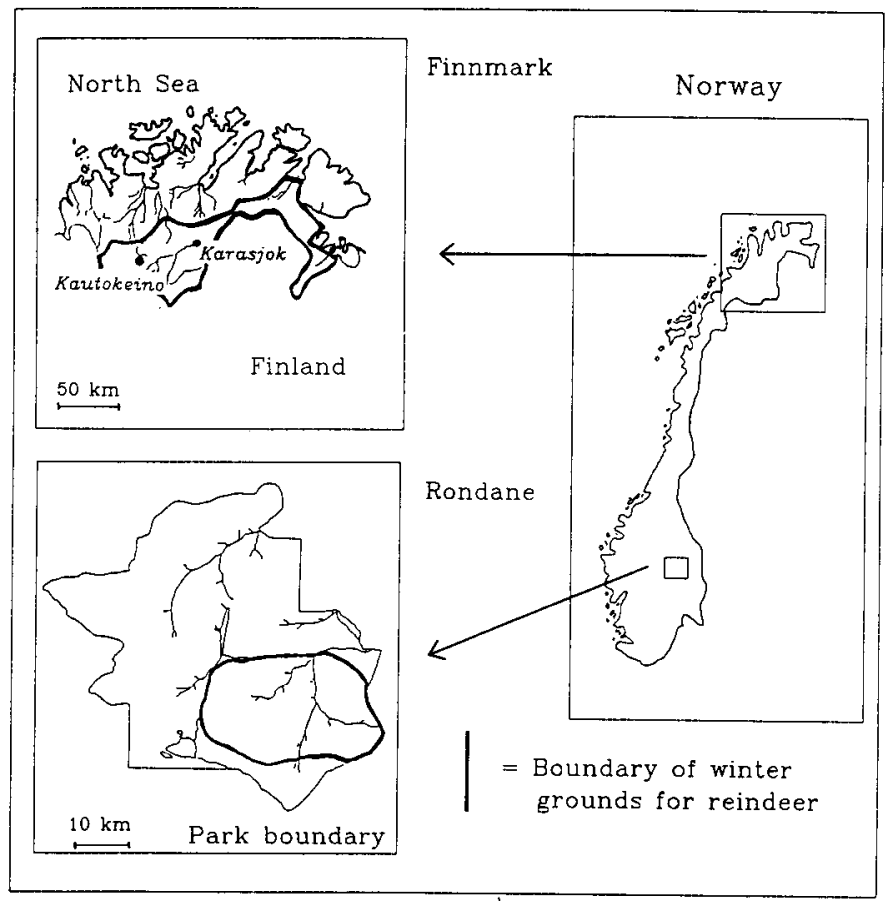

FIG. 1. The location of the study areas in Norway. The boundaries of the reindeer winter grounds are shown (Vorren, 1962; Dahle and Gjelland, 1990; Hætta et al., 1994). the comparison of terrain structure in potential winter habitats was restricted to accessible areas only, defined as areas with slopes $<35^{\circ}$ (Thing, 1984).

A simple index of terrain ruggedness based on 1:50 000 topographical maps with $20 \mathrm{~m}$ contour intervals was used for the terrain analysis (Nellemann and Thomsen, 1994). The index takes into account slope (Beasom et al., 1983; Olesen, 1990) and terrain undulations. Fluctuations in terrain surface are particularly important, since they cause gradients in snow and vegetation patterns (Shaver et al., 1990). Within each $3 \times 3 \mathrm{~km}$ site, a transect $3 \mathrm{~km}$ long was placed across the center (Fig. 2). Since ruggedness may vary independent of slope direction within each cell, we used the transect with the highest possible index value out of four possible for each cell (Fig. 2). The highest value was the one obtained from the transect crossing the greatest number of changes in aspect within the cell. A measure of terrain ruggedness can be derived from the following equation:

\section{Terrain Ruggedness Index $T R I=(\mathrm{TNC} \times \mathrm{TNF}) /(\mathrm{TNC}+\mathrm{TNF})$}

where TNC equals the total number of contour intercepts along the transect, and TNF equals the total number of fluctuations ("ups and downs") defined by the number of separate aspects along the transect (Fig. 2). This ratio mathematically incorporates both the effects of slope and terrain undulations. It is much less sensitive to extreme values of one of these components than, for example, the product or the quotient of the two factors alone. An area with considerable changes in relief (many bluffs and hollows) and many contour intercepts will thus obtain high values of ruggedness, while smooth but steep terrain will receive low values.

To determine at which contour intervals terrain ruggedness reflected availability of windblown bluffs, we compared terrain ruggedness indices for the same transects using different maps and related these indices to snow measurements. Ten transects, each $1 \mathrm{~km}$ long, were randomly chosen. Terrain ruggedness indices were calculated from maps with contour intervals of $10 \mathrm{~m}, 20 \mathrm{~m}, 30 \mathrm{~m}$ and $110 \mathrm{~m}$ along the same transects.

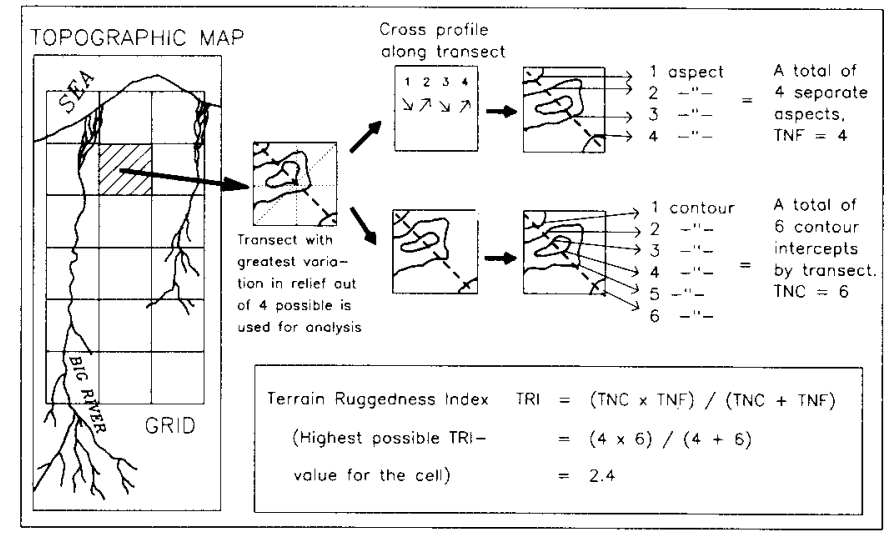

FIG. 2. The calculation of terrain ruggedness indices (TRI) on a topographic map. 
On these transects, snow measurements were conducted during early April 1993. Snow depths were recorded for every transect on 10 plots, each $2 \times 20 \mathrm{~m}$, and spaced $100 \mathrm{~m}$ apart along the transect. Within each plot, 10 snow depths were recorded. Thus 100 snow depths were recorded on every transect, giving a total of 1000 snow depths. Potential feeding locations were simply defined as any plot with less than $40 \mathrm{~cm}$ snow cover. Bluffs in this area are generally dominated by Cetraria and Cladina communities. By comparing the frequency of potential feeding locations (snow depth $<40 \mathrm{~cm}$ ) with terrain ruggedness indices derived from the four different maps, we could determine at which resolutions terrain ruggedness best reflected forage availability.

Statistical analysis was performed in SIGMASTAT. Our data were found to be non-normally distributed (KolmogorovSmirnov test), and non-parametric tests were used. Comparisons of terrain ruggedness indices, fluctuations in terrain surface and contour densities between high- and low-use areas were done using Kruskal-Wallis ANOVA with Student-Newman-Keuls test for individual comparisons. Assessments of the relationship between number of potential feeding sites and terrain ruggedness at different scales was done using Spearman's rank correlation. Regression curves were drawn using polynomial regression. Probability values $<0.05$ were considered statistically significant.

\section{RESULTS}

Terrain ruggedness at $20 \mathrm{~m}$ contour intervals was found to be significantly higher $(p<0.001)$ in areas classified as highuse compared with low-use areas for both Rondane and Finnmark (Table 1). Terrain was generally more rugged in Rondane than in Finnmark (Table 1). Contour densities alone revealed no characteristic differences between high- and lowuse areas. Low-use areas in Rondane had much higher contour densities than high-use areas in Finnmark, primarily reflecting differences in the general landscape types. However, using the terrain ruggedness index, differences between high- and low-use areas were clearly revealed.

TABLE 1. Terrain ruggedness indices and other variables derived from 1:50 000 topographic maps at 80 sites (each $9 \mathrm{~km}^{2}$ ) in reindeer winter grounds with high use ( $>150$ days in winter) and low use ( $<150$ days) in central (Rondane) and northern Norway (Finnmark).

\begin{tabular}{lccccc}
\hline \hline \multirow{2}{*}{$\begin{array}{l}\text { Terrain } \\
\text { variable }\end{array}$} & \multicolumn{2}{c}{ Rondane } & & \multicolumn{2}{c}{ Central Finnmark } \\
\cline { 2 - 3 } Contour intercepts km & High use & Low use & & High use & Low use \\
Terrain undulations km & $6.3 \pm 0.5 \mathrm{a}$ & $5.2 \pm 0.5 \mathrm{~b}^{1}$ & & $2.1 \pm 0.1 \mathrm{c}$ & $1.9 \pm 0.2 \mathrm{c}^{1}$ \\
Terrain ruggedness & $3.3 \pm 0.1 \mathrm{a}$ & $0.8 \pm 0.1 \mathrm{~b}$ & & $1.5 \pm 0.1 \mathrm{a}$ & $0.8 \pm 0.0 \mathrm{~b}$ \\
Number of sites & 20 & $2.0 \pm 0.1 \mathrm{~b}$ & $2.6 \pm 0.2 \mathrm{c}$ & $1.5 \pm 0.1 \mathrm{~d}$ \\
\hline \hline
\end{tabular}

${ }^{1}$ Different letters indicate significant differences $(p<0.05)$ (within row only) using Kruskal-Wallis ANOVA with Student-Newman-Keuls test.
A clear scale-dependent relationship between availability of potential feeding locations and terrain ruggedness was found (Fig. 3a,b). Correlations were best for terrain ruggedness indices calculated at fine scales using maps with $10-20$ m contours $(\mathrm{r}=0.85, p<0.01 ; \mathrm{r}=0.94, p<0.01$, respectively) (Fig.3b). However, no relationship between terrain ruggedness and availability of potential feeding locations was observed when maps with $30 \mathrm{~m}$ or $110 \mathrm{~m}$ contour intervals were used ( $\mathrm{r}=-0.024, p=0.62$, and $\mathrm{r}=0.24, p=0.31$, respectively). This means that fine-scale ruggedness was found to be more important for explaining forage availability than larger-scale surface patterns.
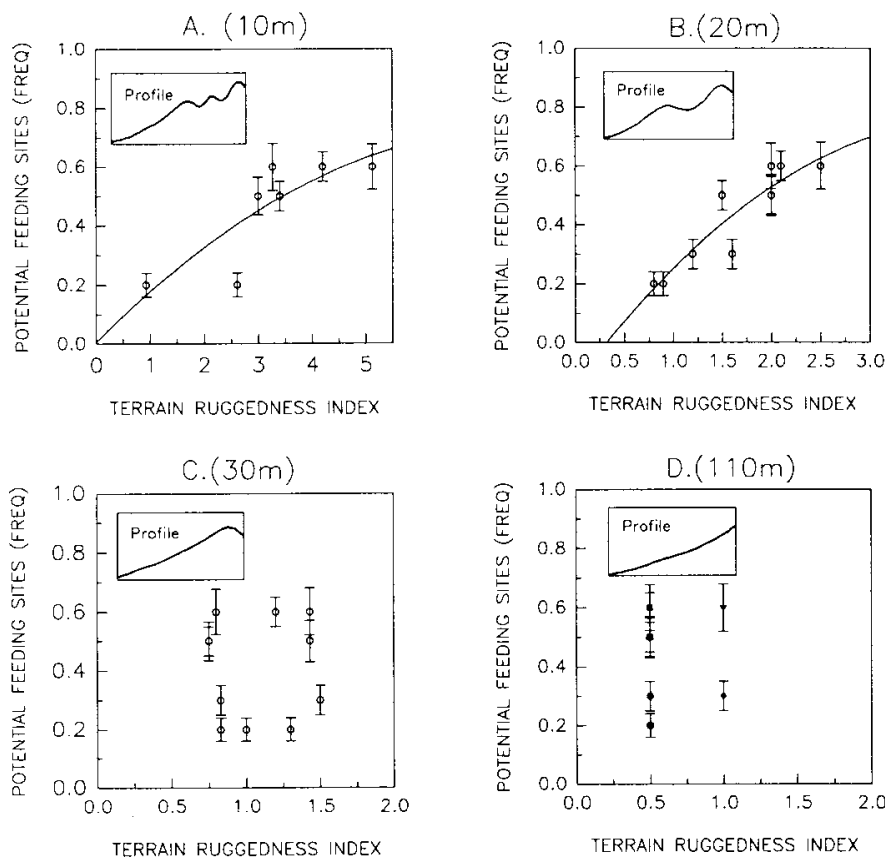

FIG. 3a-d. Relationship between terrain ruggedness and frequency (mean \pm SE) of potential feeding sites (defined as snow depth $<40 \mathrm{~cm}$ ) using maps with different contour intervals $(10,20,30,110 \mathrm{~m})$ for the same sites in Rondane, 1993. The cross profile for one specific site is shown for all 4 resolutions.

\section{DISCUSSION}

Fine-scale terrain ruggedness $(10-20 \mathrm{~m}$ contour interval) reflected forage availability well (Fig. 3a,b), corresponding with the higher ruggedness values observed for high-use areas at these scales (Table 1). In windy alpine areas, blown snow accumulates in hollows, and bluffs and ridges are exposed (Pruitt, 1959; Duquette, 1988). Access to forage in these fine-scale rugged terrain types is therefore easier than in smoother terrain where snow cover will be more even (Pruitt, 1979). In this study, the winter grounds were characterized by high availability of rugged terrain which provided a high concentration of windblown bluffs with easy access to forage (Thing, 1984; Gates et al., 1986). In early winter, snow is generally less packed, and reindeer can access and feed on the thicker lichen cover in low-lying terrain (Skogland, 1978). As winter progresses, snow depth and snow hardness increase, and reindeer are continuously forced onto wind- 
blown bluffs at higher elevations where lichen biomass tends to be lower (Skogland, 1978). Mean snow depth and snow hardness may therefore be relatively more important in less rugged terrain, which has fewer windblown bluffs and associated forage, while rugged terrain generally provides accessible forage in late winter. Rugged terrain may be particularly important to reindeer in late winter, when parturient reindeer are sensitive to starvation (Gates et al., 1986).

Investigations of the vegetation distribution in Rondane have shown that lichen heath communities determined from aerial photographs covered ca. $30 \%$ of the winter area (Dahle and Gjelland, 1990), which was close to the percentage found for several other areas in Rondane unused by reindeer in winter. While availability of lichen communities is a prerequisite for habitat selection in winter, the results in this study show that terrain structure is also of considerable importance. These patterns suggest that potential habitat may constitute less than that expected from vegetation distribution alone. Over $30 \%$ of Rondane consists of lichen heath communities, but many of these are located in smooth terrain. In late winter when snowcover greatly restricts accessibility to forage, vegetation distribution may therefore no longer reflect forage availability in smoother terrain. Estimates of general snow depth alone using remote sensing may not provide sufficient information, particularly since such analysis becomes inaccurate in rugged terrain (Hall et al., 1991). The same inaccuracy is present when attempting extrapolations from field measurements of snow characteristics (Jacobs, 1989). Combining indices of terrain ruggedness with maps of the distribution of lichen heath communities, however, offers a powerful tool for classifying potential winter habitats for reindeer when high-resolution terrain maps are available (Fig. 3a,b). Where digital terrain maps (DTMs) are available at $20 \mathrm{~m}$ resolution or higher, a fully automatic analysis of terrain ruggedness is possible.

Analysis of terrain structure can also be performed using other approaches, but most of these are very field labourintensive, such as Fourier analysis (Kaufman and Calkin, 1988) or field measurements of slope characteristics (McNab, 1993). Indices based on contour densities alone (Beasom et al., 1983) are simple in use, but do not differentiate between undulating terrain and steep, smooth terrain when contour densities are similar, as they were for the high- and low-use areas in this study. Methods based on contour densities will reflect the general landscape type (e.g., the rolling hills in Finnmark compared to the mountainous Rondane) but provide little information on landscape characteristics within these landscapes (Table 1).

Specific terrain components such as ruggedness seldom occur in random patterns, but rather in patches of various sizes, shapes and configurations (Forman and Godron, 1981; Weins et al., 1993). Maps of terrain ruggedness can be subjected to pattern analysis by applying traditional pointpattern analysis techniques, such as the nearest neighbour techniques of Clark and Evans (1954), or to textural and fractal analyses (Palmer, 1988; Milne, 1990; Musick and Grover, 1990). Comparisons of spatial patterns of terrain ruggedness and suitability of areas for reindeer wintering can then be compared for different regions using such methods, and may provide a complement to the analysis demonstrated here.

More importantly, the terrain ruggedness index can be used to identify patterns of landscape ruggedness even within a generally "flat" area like an arctic coastal plain, important for calving caribou (Thing, 1984; Eastland et al., 1989; Fancy and Whitten, 1991). While therefore "steep" caprine and "flat" cervine habitats can be distinguished statistically using maps with large contour intervals, analysis of terrain ruggedness using small contour intervals may be applied to differentiate between terrain characteristics within each general landform. Analysis of terrain ruggedness is best conducted within each general landform, since analysis across areas with great differences in contour densities (plains versus mountainous areas) will be less likely to reveal subtle differences in surface ruggedness (Beasom et al., 1983). Where size of features of biological interest demand a smaller grid cell than can be analyzed by this method from maps, then the existing topographic data must be supplemented with additional elevation data at a finer resolution, e.g., derived from stereoscopic aerial photographs or field measurements. From experience, we have found that landscapes are best characterized when the number of contours per grid cell is in the range of 5 to 15 .

We conclude that the resolution and occurrence of rugged terrain constitute important characteristics of reindeer winter habitats. The quantitative analysis of terrain ruggedness using terrain ruggedness indices at different resolutions and spatial scales can therefore provide a useful and inexpensive tool for the analysis of ungulate habitats in northern regions, and a wider range of wildlife-habitat relationships.

\section{REFERENCES}

ADAMCZEWSKI, J.Z., BATES, C.C., SOUTAR, B.M., and HUDSON, R.J. 1988. Limiting effects of snow on seasonal habitat use and diets of caribou (Rangifer tarandus groenlandicus) on Coats Island, Northwest Territories, Canada. Canadian Journal of Zoology 66:1986-1996.

BEASOM, S.L., WIGGERS, E.P., and GIARDINO, J.R. 1983. A technique for assessing landscape surface ruggedness. Journal of Wildlife Management 47:1163-1166.

BERGERUD, A.T., and PAGE, R.E. 1987. Displacement and dispersion of parturient caribou as antipredator tactics. Canadian Journal of Zoology 65:1597-1606.

BRÅTÅ, H. 1986. Villrein og ferdsel i Rondane. M.Sc. dissertation, University of Oslo, Norway. 112 p.

CHERNOV, Y.I. 1985. The living tundra. Cambridge: Cambridge University Press. 213 p.

CLARK, P.J., and EVANS, F.C. 1954. Distance to nearest neighbour as a measure of spatial relationships in populations. Ecology $35: 445-453$.

DAHLE, E., and GJELLAND, M. 1990. GIS i forvaltning av nasjonalpark. M.Sc. dissertation, Agricultural University of Norway, Ås, Norway. 95 p. 
DUQUETTE, L.S. 1988. Snow characteristics along caribou trails and within feeding areas during spring migration. Arctic 41: 143-144.

EASTLAND, W.G., BOWYER, R.T., and FANCY, S.G. 1989. Caribou calving sites relative to snowcover. Journal of Mammalogy 70:824-828.

FANCY, S.G., and WHITTEN, K.R. 1991. Selection of calving sites by Porcupine Caribou Herd. Canadian Journal of Zoology 69:1736-1743.

FORMAN, T.T., and GODRON, M. 1981. Patches and structural components for a landscape ecology. Bioscience 31:733-740.

GATES, C.C., ADAMCZEWSKI, J., and MULDERS, R. 1986. Population dynamics, winter ecology and social organization of Coats Island caribou. Arctic 39:216-222.

HÆTTA, J.I., SARA, O.K., and RUSHFELDT, I. 1994. Reindriften i Finnmark-Lovgivning og distriktsinndeling. Report from the Norwegian Reindeer Administration, Alta, Norway. 124 p.

HALL, D.K., STURM, M., BENSON, C.S., CHANG, A.T.C., FOSTER, J.L., GARBEIL, H., and CHACHO, E. 1991. Passive microwave remote and in situ measurements of arctic and subarctic snow covers in Alaska. Remote Sensing of the Environment 38:161-172.

JACOBS, J.D. 1989. Spatial representativeness of climatic data from Baffin Island, N.W.T., with implications for muskoxen and caribou distribution. Arctic 42:50-56.

KAUFMAN, D.S., and CALKIN,P.E. 1988. Morphometric analysis of Pleistocene glacial deposits in the Kigluaik mountains, Northwestern Alaska, U.S.A. Arctic and Alpine Research 20:273-284.

KLEIN, D.R. 1990. Variation in quality of caribou and reindeer forage plants associated with season, plant part and phenology. Rangifer Special Issue 3:123-130.

MATTHES-SEARS, U., MATTHES-SEARS, W.C., HASTINGS, S.J., and OECHEL, W.C. 1988. The effects of topography and nutrient status on the biomass, vegetative characteristics, and gas exchange of two deciduous shrubs on an arctic tundra slope. Arctic and Alpine Research 20:342-351.

McNAB, W.H. 1993. A topographic index to quantify the effect of mesoscale landform on site productivity. Canadian Journal of Forest Research 23:1100-1107.

MILNE, B.T. 1990. Lessons from applying fractal models to landscape patterns. Ecological Studies 82:199-235.
MURRAY,C., and MILLER, P.C. 1982. Phenological observations of major plant growth forms and species in montane and Eriophorum vaginatum tussock tundra in central Alaska. Holarctic Ecology 5:109-116.

MUSICK, H.B., and GROVER, H.D. 1990. Image textural measures as indices of landscape pattern. Ecological Studies 82:77-103.

NELLEMANN, C., and THOMSEN, M.G. 1994. Terrain ruggedness and caribou forage availability during snowmelt on the Arctic Coastal Plain, Alaska. Arctic 47:361-367.

OLESEN, C.R. 1990. Population development and ecology of muskoxen in Angujartorfiup nunaa, West Greenland. Greenland Home Rule, Department for Environment and Wildlife Management, Technical Report 16, April 1990. 85 p.

PALMER, M.W. 1988. Fractal geometry: A tool for describing spatial patterns of plant communities. Vegetatio 75:91-102.

PRUITT, W.O. 1959. Snow as a factor in the winter ecology of the barren ground caribou (Rangifer arcticus). Arctic 12:158-179. . 1966. Animals in the snow. Scientific American 202: 60-68.

. 1979. A numerical snow index for reindeer (Rangifer tarandus) winter ecology (Mammalia, Cervidae). Annales Zoologici Fennici 16:271-280.

SHAVER, G.R., NADELHOFFER, K.J., and GIBLIN, A.E. 1990. Biogeochemical diversity and element transport in a heterogenous landscape, the North Slope of Alaska. Ecological Studies 82: $105-125$.

SKOGLAND, T. 1978. Characteristics of the snow cover and its relationship to wild mountain reindeer (Rangifer tarandus tarandus L.) feeding strategies. Arctic and Alpine Research 10:569-580

1984. Life history characteristics of wild reindeer (Rangifer tarandus tarandus L.) in relation to their food resources: Ecological effects and behavioral adaptations. Holarctic Ecology 7:345-379.

THING, H. 1984. Feeding ecology of the West Greenland caribou (Rangifertarandus groenlandicus) in the Sisimiut-Kangerlussuaq region. Danish Review of Game Biology 12:1-55.

VORREN, O. 1962. Finnmarkssamenes nomadisme I-II. Oslo: Universitetsforlaget. $257 \mathrm{p}$.

WEINS, J.A., STENSETH, N.C., VAN HORNE, B., and ILMS, R. 1993. Ecological mechanisms and landscape ecology. Oikos $66: 369-380$. 